\title{
Teknologi Informasi Desa, Upaya Meningkatkan Partisipasi dan Keterampilan Masyarakat Dalam Pembangunan Desa
}

\author{
Fadilla Oktaviana*1, Ida Nuraida ${ }^{2}$ \\ 1,2Program Studi Pendidikan Bahasa Inggris, Fakultas Keguruan dan Ilmu Pendidikan, Universitas Banten \\ Jaya \\ *e-mail: fadillaoktaviana@unbaja.ac.id ${ }^{1}$
}

\begin{abstract}
The aim of the Community Service Program, Kuliah Kerja Nyata-Pembelajaran dan Pemberdayaan Kepada Masyarakat (KKN-PPM) is to improve the skills of society in Sindanglaya village, Cinangka. The problem faced does not know the use the waste of plastic to produce the useful and selling value products. The method of implementing this service is through (1) Survey through observation, interviews, and analysis of problems and potential of the village, (2) Training on making paving block from the waste of plastic. The results of this program are increasing knowledge and skills of the community regarding training on making paving block from the waste of plastic. This program is expected to facilitate the community in increasing their knowledge and skills in processing the waste materials into products that are useful and have selling value, therefore that the societies in Sindanglaya become productive communities.
\end{abstract}

Keywords: Community Learning and Empowerment, Plastic Waste Management, Paving Block

\begin{abstract}
Abstrak
Tujuan Program Pengabdian Masyarakat Kuliah Kerja Nyata-Pembelajaran dan Pemberdayaan Kepada Masyarakat (KKN-PPM) adalah untuk meningkatkan keterampilan masyarakat di Desa Sindanglaya, Kecamatan Cinangka. Permasalahan yang dihadapi yaitu belum mengetahui pemanfaatan limbah plastik untuk menghasilkan produk yang berguna dan memiliki nilai jual. Metode pelaksanaan pengabdian ini yaitu melalui (1) survey melalui pengamatan, wawancara, dan analisis permasalahan dan potensi desa, (2) pelatihan pembuatan paving blok dari limbah plastik. Hasil dari program ini adalah bertambahnya pengetahuan dan keterampilan masyarakat mengenai pengolahan limbah plastik menjadi paving blok. Program ini diharapkan dapat memfasilitasi masyarakat dalam meningkatkan pengetahuan dan keterampilan dalam mengolah bahan bekas menjadi produk yang berguna dan memiliki nilai jual, sehingga masyarakat desa Sindanglaya menjadi masyarakat yang produktif.
\end{abstract}

Kata kunci: Pembelajaran dan Pemberdayaan Masyarakat, Pengolahan Limbah plastik, paving blok

\section{PENDAHULUAN}

Pada zaman dahulu, sekitar Tahun 1928 keberadaan Desa Sindang Laya sudah dikenal sebagai bagian dari wilayah Kecamatan Cinangka, Kewedanaan Anyar Kabupaten Serang, merupakan Desa Induk yang mengandung arti bahwa "Sindang berarti Singgah atau Mampir, sedangkan Laya mempunyai arti Layon/betah/kerasan, yang berkesimpulan bahwa, setiap orang yang mampir/singggah di wilayah ini maka akan merasa betah sampai akhir hayatnya" (Napan, 2017). Hal itu terbukti sampai sekarang bahwa warga masyarakat Desa Sindanglaya terdiri dari masyarakat sekitar dan saat ini sudah berbagai suku yang berasal dari berbagai daerah Indonesia yang (majemuk), oleh karena itu tugas kedinasan, perniagaan adalah sector penting (BPS, 2014).

Sebagian besar penduduk sekitar bekerja disektor perkebunan, pertanian, memanfaat lahan kosong. Namun, pada pertengahan tahun 2000 Desa Sindanglaya dikenal sebagai daerah pesisir dan panorama pantai yang indah, sehingga penduduk sekitar beralih profesi yang mata pencaharian sebagian besar pedagang warung pantai,dan pantai banyak pengunjung wisatawan asing, sehingga dapat meningkatkan perekonomian warga Desa Sindanglaya (Desa, 2015). Peningkatan ekonomi terlihat pesat setelah di bukanya Pantai Pasir Putih Florida Indah yang terletak disebelah barat Kantor Desa Sindanglaya, dimana para pedagang diprioritaskan untuk warga Desa Sindanglaya. Bukan hanya pantai saja Desa Sindanglaya sebagian penduduk tinggal di daerah pegunungan yang masih asri, dan mempunyai beberapa mata air/sumber yang digunakan penduduk sebagai air minum yang sehat,dan banyak pengunjung wisata local yang ingin mendaki gunung tersebut dan melihat pemandangan yang indah dipuncak gunung tersebut. 
Kantong plastik merupakan penyumbang sampah plastik terbesar karena masyarakat menggunakan lebih dari 100 miliar kantong plastik per tahun (Widodo, dkk. 2018). Pemilahan sampah adalah kegiatan mengelompokkan dan memisahkan sampah sesuai dengan jenisnya. Sedangkan pewadahan adalah kegiatan menampung sampah sementara dalam suatu wadah individual atau komunal di tempat sumber sampah dengan mempertimbangkan jenis-jenis sampah (Setiadi, 2015). Karena potensinya yang cukup besar, alangkah lebih baik untuk memanfaatkan sampah plastik ini menjadi produk dan jasa kreatif dalam rangka mengelola sampah plastik dengan baik, sehingga plastik benar-benar mendukung kehidupan kita (Amran, 2016).

Sebagai desa yang letaknya di pinggir pantai, banyak masyarakatnya yang memiliki aktivitas berdagang. Pantai Pasir Putih adalah salah satu pantai yang terkenal di kawasan pantai anyer. Pantai ini sangat ramai dikunjungi oleh wisatawan, baik domestik atau asing, terutama pada hari libur atau pada saat liburan baik libur sekolah atau hari libur yang lainnya. Pantai Pasir Putih terletak tepat didepan Desa Sindanglaya, Kecamatan Cinangka, oleh karena itu banyak masyarakat di desa tersebut yang menggantungkan nasibnya melalui berjualan.

Dengan banyaknya masyarakat Desa Sindanglaya yang melakukan aktivitas jual beli, maka meningkatnya penggunaan plastik yang mengakibatkan banyaknya sampah plastik yang dihasilkan. Sampah plastik, seperti yang kita ketahui sangat sulit untuk terurai dan membutuhkan waktu yang sangat lama. Oleh karena itu, harus ada edukasi kepada masyarakat bagaimana cara memanfaatkan limbah plastik agar menjadi produk yang berguna dan juga bernilai jual.

Dari hasil survey yang dilakukan melalui pengamatan dan wawancara, belum adanya pengetahuan dan keterampilan masyarakat mengenai pengolahan limbah plastik bekas. Yang dilakukan oleh masyarakat selama ini hanya membuang atau mengumpulkan kepada penjual atau pengepul plastik yang ada di desanya. Dengan membuang plastik sembarangan, maka akan merusak lingkungan karena plastik tidak dapat terurai dan membutuhkan waktu yang sangat lama. Oleh karena itu, dalam kegiatan KKN-PPM merupakan wujud pengabdian dan tanggung jawab perguruan tinggi terhadap masyarakat (Dikti, 2018; Wardany, dkk. 2020). Secara lebih spesifik KKN-PPM ini berupaya meningkatkan pengetahuan dan keterampilan masyarakat desa khususnya kaum bapak di Desa Sindanglaya, Kecamatan Cinangka dalam pengolahan limbah plastik untuk menghasilkan produk yang berguna dan memiliki nilai jual.

\section{METODE DAN BAHAN}

Metode pelaksanaan yang digunakan selama proses pelatihan diantaranya adalah (1) pembekalan kepada mahasiswa pendamping lapangan yang dilaksanakan di universitas Banten Jaya dengan pemateri Bapak Syarif Hidayat, ST., M.Eng dari PT. Pentaza Multikarya yang menjadi salah satu mitra pada kegiatan KKN-PPM ini, (2) pelaksanaan pelatihan pada masyarakat di desa Sindanglaya yang diawali dengan pemberian materi mengenai bahaya limbah plastik, (3) Demonstrasi dan Praktek Pembuatan paving blok dengan limbah plastik oleh Tim KKN-PPM, mahasiswa pendamping, dan masyarakat.

Tujuan dari program pengabdian masyarakat kali ini adalah untuk memberikan pelatihan dan pendampingan penggunaan sampah plastik dan botol plastik menjadi paving block. Dengan memanfaatkan sampah menjadi suatu produk yang berdaya jual tinggi. Mengenai bahan dan prosedur pembuatan paving blok dari limbah plastik adalah sebagai berikut (Siregar, 2019):
Bahan :
a. Pasir
b. Ayakan
c. Plastik
d. Press Paving block
e. Plastik Crusher
f. Pengaduk 


\section{g. Kompor}

Prosedur :
a. Memilah sampah plastik dari keseluruhan sampah anorganik.
b. Mengayak pasir untuk dijadikancampuran paving block.
c. Memanaskan pasir dengan kompor gas yang memiliki $4000 \mathrm{kkal} / \mathrm{jam}$ hingga suhu \pm $300^{0} \mathrm{C}$.
d. Kemudian plastik dimasukkan sedikit demi sedikit sehingga komposisinya pas dan diaduk rata.
e. Mencetak campuran pasir dan plastik.
f. Mengeringkan campuran.

Adapun diagram alur proses pembuatan paving blok dari limbah plastik adalah sebagai berikut (Sumarjo, Jojo, Eri Widianto, 2019):

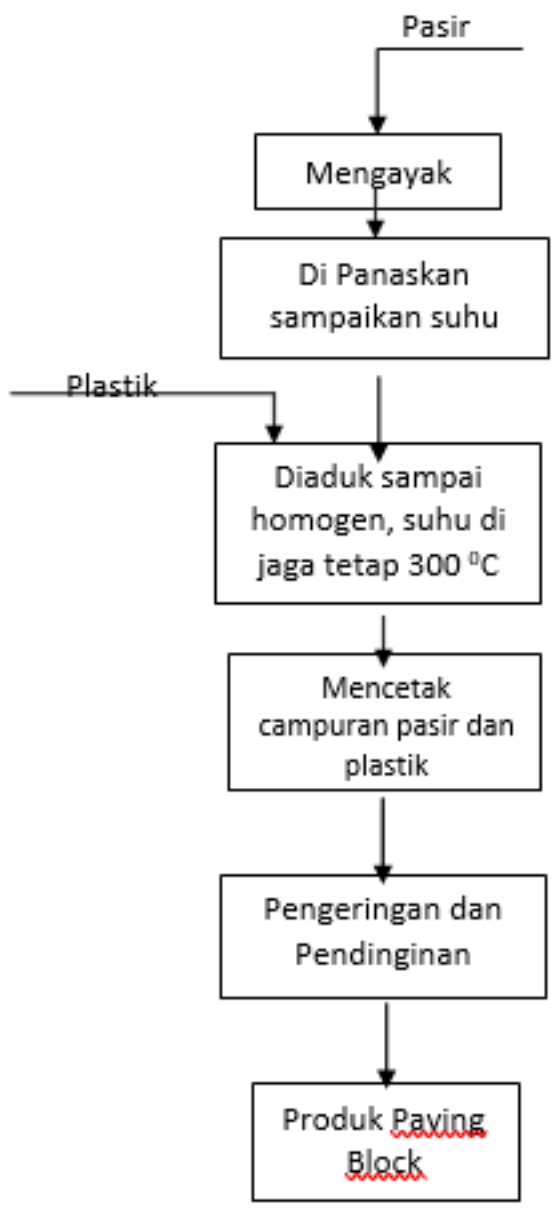

Gambar 1 Diagram alur proses pembuatan paving blok dari limbah plastik

\section{HASIL DAN PEMBAHASAN}

a. Pembekalan Kepada Mahasiswa pendamping lapangan

Kegiatan yang pertama kali dilakukan adalah pembekalan kepada mahasiswa pendamping lapangan mengenai materi pelatihan yang akan dilaksanakan di Desa Sindanglaya, dalam hal ini materi yang disampaikan mengenai pengolahan limbah plastik menjadi paving blok. Berikut ini adalah dokumentasi kegiatan pembekalan mengenai proses pembuatan paving blok: 


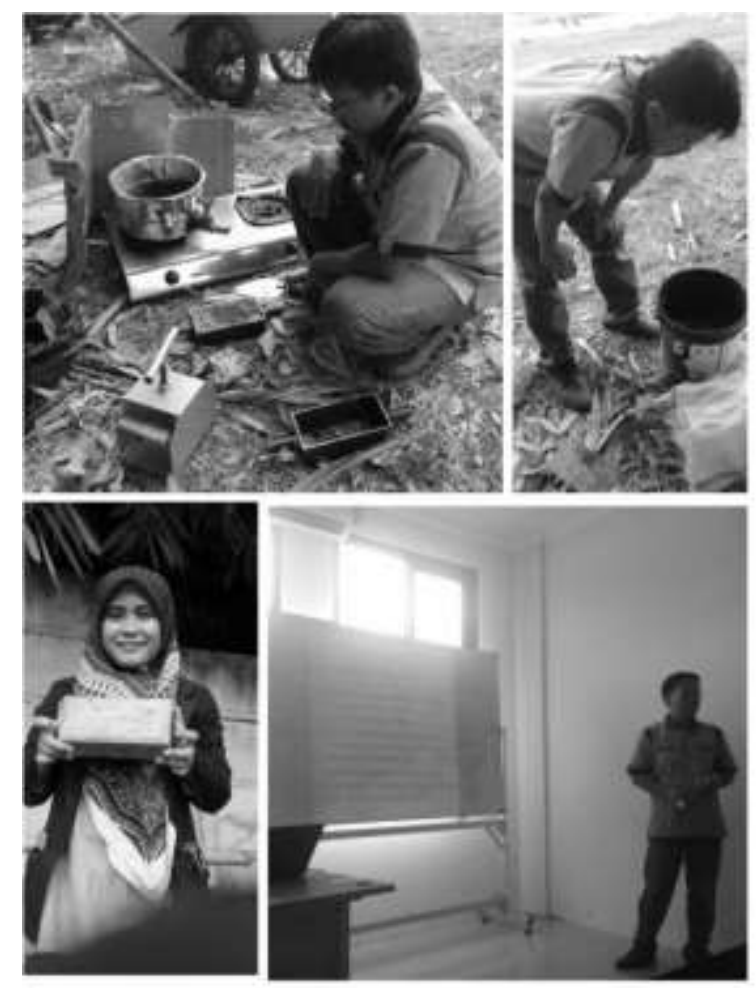

Gambar 2. Kegiatan Pembekalan Mahasiswa Pendamping, teori dan praktek

Kegiatan ini dilaksanakan di Universitas Banten Jaya, Kampus 2 yang beralamat di Jln. Syeikh Nawawi Al Bantani, Curug, Kota Serang pada hari Jum'at, 28 Juni 2019 dengan pemateri Bapak Syarif Hidayat, ST., M.Eng sebagai perwakilan dari mitra KKN-PPM yaitu PT. Pentaza Multikarya. Kegiatan ini dibuka langsung oleh ketua LP3M Universitas Banten Jaya, Nur Hidayanti, M.Pd. Selanjutnya, kegiatan pembekalan ini dibagi kedalam dua sesi yaitu sesi pertama penyampaian materi cara membuat paving blok dari limbah plastik dan sesi kedua praktek membuat paving blok.

b. Pelaksanaan pelatihan; pemberian materi mengenai bahaya limbah plastik dan cara pemanfaatannya

Kegiatan selanjutnya yaitu pelaksanaan KKN-PPM di Desa Sindanglaya dengan tema "Teknologi Informasi Desa, Upaya Meningkatkan Partisipasi dan Keterampilan Masyarakat dalam Pembangunan Desa (Pemanfaatan Limbah Plastik menjadi Paving Blok di Desa Sindanglaya, Kec. Cinangka)". Kegiatan dilaksanakan pada hari sabtu, 29 Juni 2019. Kegiatan ini difokuskan kepada masyarakat laki-laki (bapak-bapak) karena proses pembuatannya yang memakan waktu dan juga tenaga. Masyarakat terlihat sangat antusias karena plastik sangat sulit untuk dipisahkan dengan kehidupan sehari-hari.

Sedangkan pengetahuan untuk mengolah limbahnya masih belum dimiliki oleh masyarakat pada umumnya dan khususnya masyarakat di desa Sindanglaya, Kec. Cinangka. 


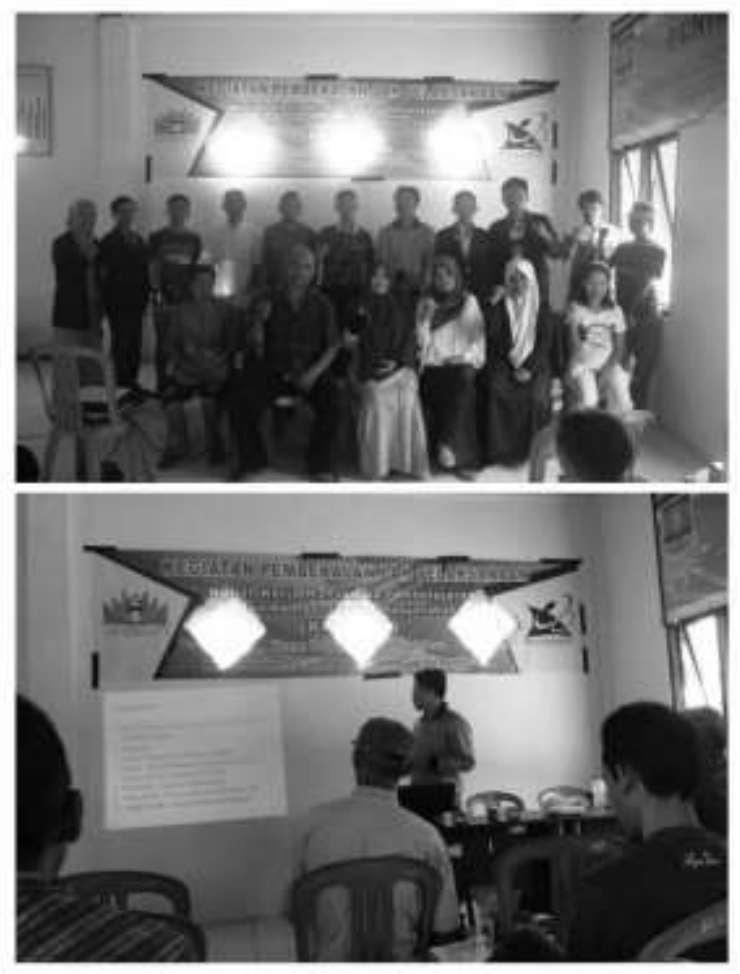

Gambar 3. Penyampaian materi mengenai cara membuat paving blok dari limbah plastik

Kegiatan ini dilaksanakan di kantor desa Sindanglaya yang dihadiri oleh sejumlah perangkat desa dan masyarakat desa dalam hal ini dikhususkan kepada ibu rumah tangga sebagai pesertanya. Ibu Hj. Kartini Edi sebagai perangkat, sebagai perwakilan dari kepala Desa Sindanglaya, Kec. Cinangka membuka kegiatan KKN-PPM ini. Kemudian dilanjutkan dengan penyampain materi mengenai proses pembuatan paving blok dari limbah plastik yang disampaikan oleh Bapak Syarif Hidayat, ST., M.Eng sebagai perwakilan dari mitra KKN-PPM yaitu PT. Pentaza Multikarya. Antusiasme terlihat tidak hanya ibu rumah tangga yang menjadi peserta pada pelatihan ini, tetapi juga bapak-bapak baik masyarakat maupun perangkat desa yang menjadi peserta juga pada kegiatan pelatihan ini. Hal ini terlihat pada sesi diskusi yaitu banyaknya pertanyaan yang disampaikan mengenai materi yang disampaikan.

\section{c. Demonstrasi pembuatan paving blok dari limbah plasik}

Kegiatan ketiga yaitu demontrasi sekaligus praktek pembuatan paving blok dari limbah plastik. Demontrasi ini dilaksanakan oleh mahasiswa pendamping serta tim dosen KKN- PPM. Kegiatan ini diselingi tanya jawab dari masyarakat, terlebih mengenai bahan, alat serta komposisi untuk menghasilkan paving blok yang ideal. Dibawah ini adalah dokumentasi mengenai proses pembuatan paving blok dari limbah plastik. 


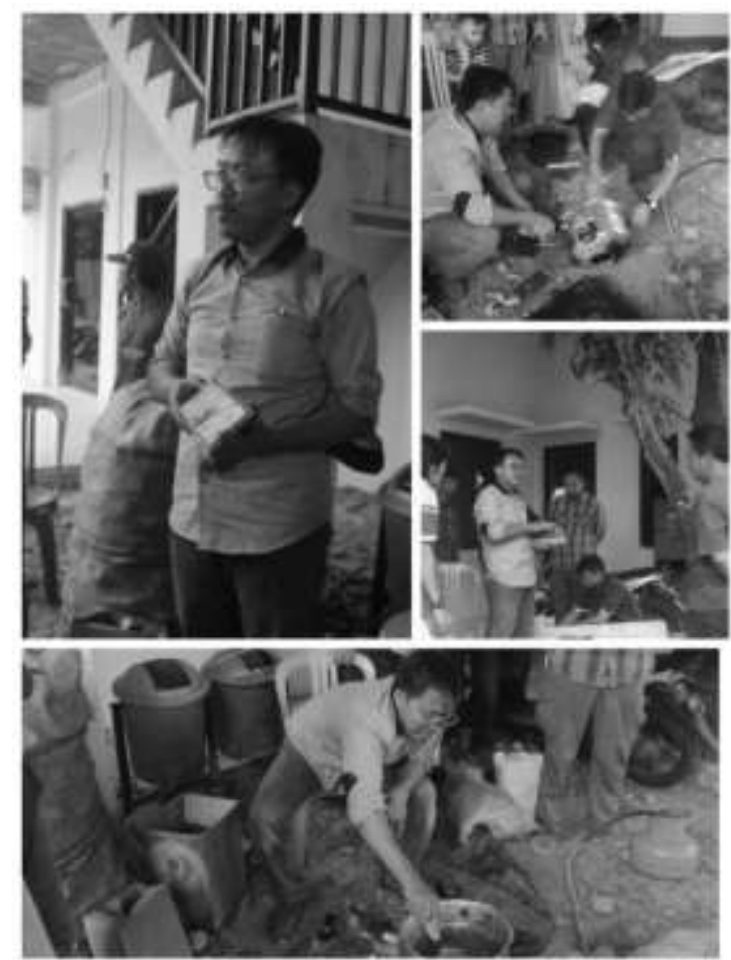

Gambar 4. Demonstrasi pembuatan paving blok dari limbah plastik

Demonstrasi ini dilakukan oleh mahasiswa yang sudah diberikan pelatihan terlebih dahulu pada kegiatan pembekalan. Sehingga pada saat kegiatan pelaksanaan KKN-PPM, mahasiswa bisa menjadi tutor dan juga pendamping bagi masyarakat. Mahasiswa yang terlibat pada kegiatan KKN-PPM ini terdiri dari lintas fakultas dan program studi yang telah mengontrak Mata Kuliah KKM di UNBAJA.

\section{KESIMPULAN}

Setelah dilakukan kegiatan Kuliah Kerja Nyata-Pembelajaran dan Pemberdayaan Kepada Masyarakat (KKN-PPM) tahun 2019 dengan tema "Teknologi Informasi Desa, Upaya meningkatkan partisipasi dan keterampilan masyarakat dalam pembangunan desa (Pemanfaatan Limbah Plastik menjadi Paving Blok di Desa Sindanglaya, Kec. Cinangka)", maka terjadi peningkatan pengetahuan dan keterampilan masyarakat tentang mengolah limbah plastik menjadi paving blok. Dengan meningkatkan pengetahuan dan keterampilan dalam mengolah bahan bekas menjadi produk yang berguna dan memiliki nilai jual, harapannya masyarakat desa sindanglaya menjadi masyarakat yang produktif.

\section{UCAPAN TERIMA KASIH}

Ucapan terimakasih disampaikan kepada :

1. Direktorat Riset dan Pengabdian Masyarakat, Direktorat Jenderal Penguatan Riset dan Pengembangan, Kementerian Riset, Teknologi, dan Pendidikan Tinggi yang telah memberikan kesempatan dan dukungan untuk melaksanakan kegiatan Kuliah Kerja NyataPembelajaran dan Pemberdayaan Kepada Masyarakat (KKN- PPM) dengan tema "Teknologi Informasi Desa, Upaya meningkatkan partisipasi dan keterampilan masyarakat dalam pembangunan desa (Pemanfaatan Limbah plastik menjadi paving block) tahun pelaksanaan 2019

2. Kepala Desa Sindang Laya yang telah bekerjasama dan memberikan kesempatan untuk dapat melakukan pengabdian di desa tersebut. 
3. PT. Pentaza Multi Karya atas kerjasamanya pada kegiatan KKN-PPM 2019 sebagai narasumber.

\section{DAFTAR PUSTAKA}

Amran, Y., 2016. Pemanfaatan Limbah Plastik Untuk Bahan Tambahan Pembuatan Paving Block Sebagai Alternatif Perkerasan pada Lahan Parkir di Universitas Muhammadiyah Metro. TAPAK (Teknologi Apl. Konstr. J. Progr. Stud. Tek. Sipil 4.

BPS, 2014. Kabupaten Serang dalam angka. Kabupaten Serang Provinsi Banten.

Desa, 2015. Profil Desa Sindanglaya.

Dikti, 2018. Panduan Penelitian dan Pengabdian kepada masyarakat edisi XII. Jakarta.

Napan, N., 2017. Pandangan Hukum Islam Terhadap Upah Usaha Pijat Lawan Jenis (Studi di Pantai Pasir Putih Anyer Florida Indah). Universitas Islam Negeri "SMH" Banten.

Setiadi, A., 2015. Studi pengelolaan sampah berbasis komunitas pada kawasan permukiman perkotaan di Yogyakarta. J. Wil. dan Lingkung. 3, 27-38.

Siregar, R., 2019. Korelasi Besar Temperatur Pemanasan Cetakan terhadap Kualitas Hasil Press Paving Block Berbahan Dasar Sampah Plastik. FLYWHEEL J. Tek. Mesin Untirta 41-45.

Sumarjo, Jojo, Eri Widianto, R.H., 2019. Pemanfaatan sampah plastik dan organik dalam pembuatan paving block menggunakan mesin press. Al-Ard J. Tek. Lingkung. 4.2.

Wardany, K., Sari, R.P., Mariana, E., 2020. Sosialisasi Pendirian "Bank Sampah" Bagi Peningkatan Pendapatan Dan Pemberdayaan Perempuan Di Margasari. Din. J. Pengabdi. Kpd. Masy. 4, 364372.

Widodo, S., Marleni, N.N.N., Firdaus, N.A., 2018. Pelatihan Pembuatan Paving Block dan Eco-Bricks dari Limbah Sampah Plastik di Kampung Tulung Kota Magelang. Community Empower. 3, 6366. 